\title{
Ab-Initio Study of Citrate Ion as an Oxygen-Rich Complexing Agent
}

\section{Armando G. Rojas-Hernández, ${ }^{1}$ Aned de Leon, ${ }^{2, \star}$ Rafael A. Sabory-García, ${ }^{1}$ Rafael Ramírez-Bon, ${ }^{3}$ Dainet Berman-Mendoza ${ }^{1}$ and Santos J. Castillo ${ }^{1}$}

${ }^{1}$ Departamento de Investigación en Física, Universidad de Sonora, Blvd. Luis Encinas y Rosales S/N, Col. Centro, Hermosillo, Sonora, México

${ }^{2}$ Centro de Investigación y Estudios Avanzados del IPN. Unidad Querétaro. Apdo. Postal 1-798, 76001, Querétaro, Qro. México

${ }^{3}$ Departamento de Ciencias Químico-Biológicas, Universidad de Sonora, Blvd. Luis Encinas y Rosales S/N, Col. Centro, Hermosillo, Sonora, México

* Corresponding author: E-mail: aned.deleon@unison.mx

Received: 08-29-2019

\begin{abstract}
Theoretical studies on conformational analysis, geometry optimizations and frequencies for citrate at the MP2/LANL2DZ level portrait it as a promising candidate for a complexing agent for cadmium (II) ion $\left(\mathrm{Cd}^{2+}\right)$ and cadmium sulfide (CdS). Natural Bond Orbital (NBO) charges, Delocalization Indices, HOMO/LUMO gaps and surfaces along with absolute electronegativity values were employed to analyze the interactions among the configurations obtained. The most stable structures involved the interaction between the LUMO of $\mathrm{Cd}^{2+} / \mathrm{CdS}$ and the most dense region of the HOMO of the citrate ion.
\end{abstract}

Keywords: HOMO/LUMO surfaces; complexing agent; CdS; citrate ion

\section{Introduction}

The synthesis of CdS films, which are used on solar cells through a cheap technique such as chemical bath deposition (CBD) [1] is highly dependable on the complexing agent used. The optimum semiconductor films are produced modulating temperature [2], $\mathrm{pH}$ [3] and reactive concentration [4]. In this technique, the thin films are deposited on substrates in contact with dilute chemical baths containing metallic ions. Thus, the morphology of the film is highly dependent on the precipitation of the solid phase. Therefore, the complexing agents play a crucial role on the structure of the thin film being deposited. One of the complexing agents used experimentally is ammonia [5]. However, its volatility and toxicity have contributed to a search for other materials. Among them, are ethylene-diamine (ED) [6], ethylenediaminetetraacetic acid (EDTA) [6], polyethyleneimine [7], acetylacetone [8] and glycine [9]. There are only a handful of complexing agents proposed and few studies on the interactions involved between complexing agents and CdS. Our aim is to propose new com- plexing agents that can show a good affinity with $\mathrm{CdS}$ to enhance the homogeneity of the morphology and structure of the film. We propose citrate ion as a complexing agent for CdS based on our previous studies $[9,10]$ that show a high relationship between the stability of CdS and an oxygen-rich complexing agent. The main goal of this paper is to analyze the participation of the oxygens in the citrate ion on the interaction between it and $\mathrm{Cd}^{2+} / \mathrm{CdS}$ through charges, delocalization indices, HOMO/LUMO and absolute electronegativity.

\section{Methodology}

We employed Gaussian 09 [11] software for ab-initio quantum mechanical calculations at the second order perturbation Møller Plesset MP2 [12] level of theory in conjunction with the LANL2DZ [13] basis set. We used global orbital cutoffs and fine convergence criteria. We examined the Hessian matrix to confirm the energy minima configurations had only positive vibrational frequencies which 
pertain to energy minima and not transition states. Basis set superposition error (BSSE) [14] calculations and zero-point energies were employed to correct the energies.

Dissociation energies $(\Delta \mathrm{E})$ were obtained from:

$$
\Delta E=E_{\text {system }}-E_{\text {citrate ion }}-E_{C d^{2+} / C d S},
$$

where system refers to the system formed by $\mathrm{Cd}^{2+}$ or $\mathrm{CdS}$ and the citrate ion. The terms $E_{\text {citrate ion }}$ and $E_{C d^{2+}} C d S$ refer to the energy in $\mathrm{kcal} / \mathrm{mol}$ of the optimized structures of the citrate ion, $\mathrm{Cd}^{2+}$ and $\mathrm{CdS}$ on an individual level, respectively. In the first set of results, we studied the systems $\mathrm{Cd}^{2+}$-citrate ion, while the second set of results pertain to the CdS-citrate ion systems. For all the systems, we calculated the difference between the Lowest Unoccupied Molecular Orbital (LUMO) and the Highest Occupied Molecular Orbital (HOMO) referred to as GAP in eV in Table 1.

We calculated absolute electronegativity, $\chi$, for all the systems [15],

$$
\chi=\frac{I+A}{2}
$$

where $-\varepsilon_{\mathrm{HOMO}}=\mathrm{I}$ and $-\varepsilon_{\mathrm{LUMO}}=\mathrm{A}$.
In addition, we report charges in au obtained via Natural Bond Orbital (NBO) analyses [16] using Gaussian 09. Delocalization indices, $\mathrm{DI}(\mathrm{A}, \mathrm{B})$ between atoms $\mathrm{A}$ and $B$, were calculated through the AIMALL software [17] to analyze bonds and interactions between the atoms in the molecular species.

\section{Results and Discussion}

The interaction between citrate ion and cadmium (pale yellow) can be considered an acid-base one. The calculated values of $\chi$ for the citrate ion and cadmium were of 4.78 $\times 10^{-20} \mathrm{~J}$ and $1.87 \times 10^{-20} \mathrm{~J}$, respectively. It is expected that $\mathrm{Cd}^{2+}$ attracts electrons and the citrate ion donates them. This is confirmed by NBO charges and delocalization indices.

Figure 1 shows the optimized geometry of citrate ion and the CdS in conjunction with their HOMO and LUMO surfaces. The energy minima configurations formed by the interaction between citrate ion and $\mathrm{Cd}^{2+}$ are depicted in Figure 2 in order of stability whereas the first structure is the most stable.

In structure 1 , the citrate ion displays 3 hydrogen bonds involving its deprotonated carboxyl groups with de-
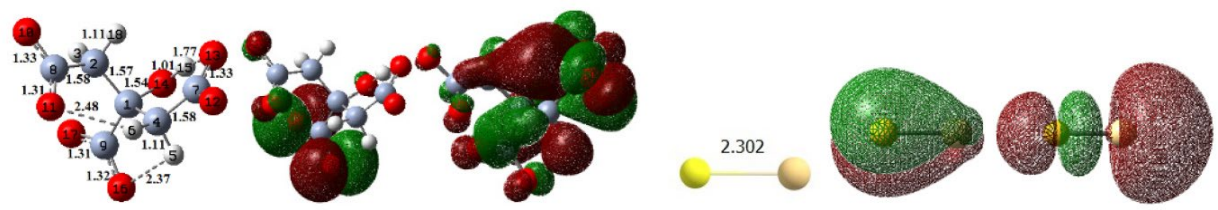

Figure 1. Selected geometrical parameters of citrate ion and CdS whereby bond lengths are in angstroms ( $)$. HOMO and LUMO surfaces are depicted for both substances.

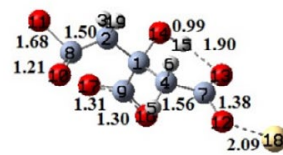

1
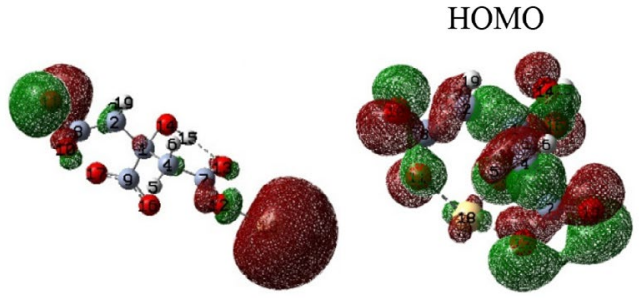

LUMO
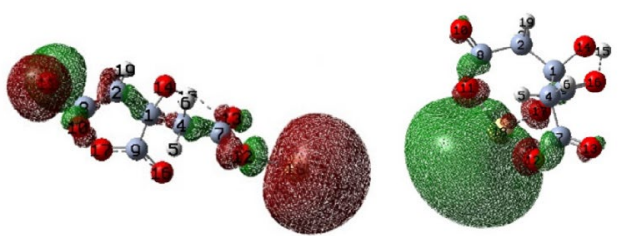

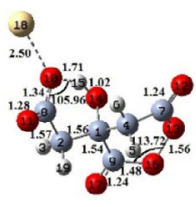

3
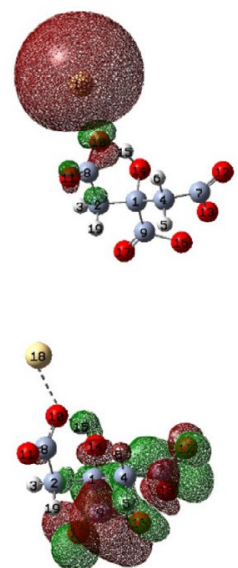

Figure 2. Selected geometrical parameters of the systems citrate ion-Cd whereby bond lengths are in angstroms ( $\AA$ ) and angles in ${ }^{\circ}$. HOMO and LUMO surfaces are depicted for all the configurations. 
localization indices of $\mathrm{DI}(\mathrm{H} 6, \mathrm{O} 11)=0.04, \mathrm{DI}(\mathrm{O} 13, \mathrm{H} 15)=$ 0.10 and $\mathrm{DI}(\mathrm{H} 5, \mathrm{O} 16)=0.04$ and distances of $2.48 \AA, 1.77$ $\AA$ and $2.37 \AA$, respectively. The first structure of Fig. 2 has a dissociation energy of $-1065.20 \mathrm{KJ} / \mathrm{mol}$. To form this structure, C4 and C7 moved their attached atoms to interact with cadmium. It shares one hydrogen bond with citrate ion from Fig.1, yet with a smaller DI $(\mathrm{O} 13, \mathrm{H} 15)=$ 0.06 . The transfer of electrons from the citrate ion to cadmium is confirmed by its decrease in charge to 0.85 au and $\mathrm{DI}(\mathrm{O} 12, \mathrm{Cd} 18)=0.51$. Structure 2 has a dissociation energy of $-798.36 \mathrm{KJ} / \mathrm{mol}$. It does not retain any of the hydrogen bonds the lone citrate ion had, which could account for an increase in energy compared to structure 1. However, its high stability is most likely supported by the interaction of $\mathrm{Cd}$ with the ion on the region where most of the citrate ion's HOMO is located. It forms 1 hydrogen bond with $\mathrm{DI}(\mathrm{H} 15, \mathrm{O} 16)=0.06$ and shows charge transfer between $\mathrm{Cd}$ and 3 oxygens with $\mathrm{DI}$ values of $\mathrm{DI}(\mathrm{O} 11, \mathrm{Cd} 18)$ $=0.47, \mathrm{DI}(\mathrm{O} 12, \mathrm{Cd} 18)=0.48, \mathrm{DI}(\mathrm{O} 17, \mathrm{Cd} 18)=0.39$ and

Table 1. MP2/LANL2DZ dissociation energies with zero point corrections, $\mathrm{HOMO} / \mathrm{LUMO}$ gaps and absolute electronegativity $(\mathrm{X})$ are listed under $\Delta \mathrm{E}(0 \mathrm{~K})$ in $\mathrm{kJ} / \mathrm{mol}$; GAP and $\mathrm{X}$ in $\left(\times 10^{-19} \mathrm{~J}\right)$, respectively, shown on Figs. 1-3.

\begin{tabular}{cccc}
\hline System & $\Delta \mathbf{E}$ & GAP & $\mathbf{X}$ \\
\hline 1 & -1065.20 & 2.40 & 0.16 \\
2 & -798.36 & 17.6 & 0.15 \\
3 & -283.34 & 2.68 & 0.15 \\
4 & -518.36 & 14.7 & 0.38 \\
5 & -514.16 & 14.8 & 0.38 \\
6 & -506.40 & 14.7 & 0.38 \\
7 & -499.44 & 14.8 & 0.31 \\
8 & -478.53 & 14.9 & 0.32 \\
9 & -470.91 & 14.9 & 0.32 \\
10 & -241.98 & 18.0 & 0.33 \\
\hline
\end{tabular}

Table 2. Delocalization Indices of citrate ion and structures 1-3.

\begin{tabular}{cccccc}
\hline A & B & $\begin{array}{c}\text { DI(A,B) } \\
\text { citrate }\end{array}$ & $\mathbf{1}$ & $\mathbf{2}$ & $\mathbf{3}$ \\
\hline C8 & O10 & 1.24 & 1.51 & 1.41 & 1.14 \\
H6 & O11 & 0.04 & - & - & - \\
C8 & O11 & 1.28 & 0.75 & 1.04 & 1.38 \\
C7 & O12 & 1.28 & 1.02 & 1.05 & 1.53 \\
C7 & O13 & 1.21 & 1.34 & 1.44 & 0.82 \\
O10 & H15 & - & - & - & 0.10 \\
O13 & H15 & 0.10 & 0.06 & - & - \\
H5 & O16 & 0.04 & - & - & - \\
C9 & O16 & 1.25 & 1.30 & 1.37 & 0.83 \\
O13 & O16 & - & - & - & 1.08 \\
H15 & O16 & - & - & 0.06 & - \\
C9 & O17 & 1.27 & 1.30 & 1.11 & 1.54 \\
O10 & Cd18 & - & - & - & 0.26 \\
O11 & Cd18 & - & - & 0.47 & - \\
O12 & Cd18 & - & 0.51 & 0.48 & - \\
O17 & Cd18 & - & - & 0.39 & - \\
\hline
\end{tabular}

distances of $2.08 \AA, 2.11 \AA$ and $2.15 \AA$, leaving Cd with a charge of $1.65 \mathrm{au}$. Structure 3 is the least stable system. It does not retain any of the lone citrate ion's hydrogen bonds. It forms a hydrogen bond with $\mathrm{DI}(\mathrm{O} 10, \mathrm{H} 15)=0.10$. It also forms a single bond between 2 oxygens, with $\mathrm{DI}(\mathrm{O} 13, \mathrm{O} 16)$ $=1.08$ which increases the repulsion between them, rising

Table 3. NBO charges in a.u. for citrate ion and systems 1-3.

\begin{tabular}{lrrrr}
\hline & citrate & \multicolumn{1}{c}{$\mathbf{1}$} & $\mathbf{2}$ & \multicolumn{1}{c}{$\mathbf{3}$} \\
\hline C1 & 0.28 & 0.28 & 0.25 & 0.25 \\
C2 & -0.54 & -0.57 & -0.54 & -0.53 \\
H3 & 0.23 & 0.32 & 0.24 & 0.25 \\
C4 & -0.56 & -0.53 & -0.56 & -0.54 \\
H5 & 0.23 & 0.25 & 0.21 & 0.24 \\
H6 & 0.25 & 0.22 & 0.27 & 0.28 \\
C7 & 1.00 & 1.08 & 0.98 & 0.99 \\
C8 & 1.00 & 1.01 & 0.99 & 0.99 \\
C9 & 1.00 & 0.95 & 0.97 & 0.98 \\
O10 & -0.98 & -0.64 & -0.76 & -1.00 \\
O11 & -0.93 & -0.47 & -1.05 & -0.80 \\
O12 & -0.93 & -1.05 & -1.04 & -0.64 \\
O13 & -0.97 & -0.84 & -0.74 & -0.34 \\
O14 & -0.93 & -0.88 & -0.87 & -0.87 \\
H15 & 0.52 & 0.54 & 0.53 & 0.56 \\
O16 & -0.95 & -0.89 & -0.79 & -0.38 \\
O17 & -0.93 & -0.88 & -1.00 & -0.63 \\
Cd18 & - & 0.86 & 1.65 & -0.02 \\
H19 & 0.20 & 0.24 & 0.26 & 0.23 \\
\hline
\end{tabular}

Table 4. Delocalization Indices of structures 4-10

\begin{tabular}{ccccccccc}
\hline & & & \multicolumn{7}{c}{ DI(A,B) } \\
A & B & $\mathbf{4}$ & $\mathbf{5}$ & $\mathbf{6}$ & $\mathbf{7}$ & $\mathbf{8}$ & $\mathbf{9}$ & $\mathbf{1 0}$ \\
\hline H6 & O10 & - & - & - & 0.04 & - & - & - \\
C8 & O10 & 1.27 & 1.27 & 1.10 & 1.20 & 1.25 & 1.19 & 1.54 \\
H6 & O11 & 0.04 & 0.04 & - & - & - & - & - \\
C8 & O11 & 1.27 & 1.27 & 1.35 & 1.19 & 1.27 & 1.22 & 0.91 \\
C9 & O11 & - & - & - & - & - & - & 0.76 \\
H3 & O12 & - & - & 0.05 & - & - & - & - \\
C7 & O12 & 1.29 & 1.33 & 1.27 & 1.28 & 1.16 & 1.25 & 1.27 \\
C7 & O13 & 1.15 & 1.09 & 1.26 & 1.23 & 1.24 & 1.28 & 1.06 \\
O10 & H15 & - & - & - & - & 0.07 & - & - \\
O12 & H15 & 0.06 & - & - & - & - & - & - \\
O13 & H15 & - & - & - & 0.09 & - & - & - \\
C9 & O16 & 1.09 & 1.34 & 1.37 & 1.24 & 1.24 & 1.30 & 0.54 \\
O13 & O16 & - & - & - & - & - & - & 1.04 \\
H15 & O16 & - & - & - & - & - & - & - \\
C9 & O17 & 1.36 & 1.10 & 1.08 & 1.31 & 1.32 & 1.24 & 1.29 \\
H15 & O17 & - & 0.07 & 0.05 & & - & 0.07 & - \\
O10 & Cd19 & - & - & 0.33 & 0.28 & - & 0.30 & - \\
O11 & Cd19 & - & - & - & 0.30 & - & 0.27 & - \\
O12 & Cd19 & - & - & - & - & 0.30 & - & 0.30 \\
O13 & Cd19 & 0.30 & 0.31 & - & - & 0.30 & - & - \\
O14 & Cd19 & - & - & - & - & - & - & 0.30 \\
O16 & Cd19 & 0.32 & - & - & - & - & - & - \\
O17 & Cd19 & - & 0.30 & 0.31 & - & - & - & - \\
S18 & Cd19 & 1.22 & 1.23 & 1.22 & 1.33 & 1.32 & 1.32 & 1.02 \\
\hline & & & & & & & &
\end{tabular}




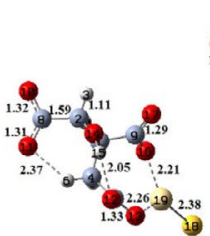

4

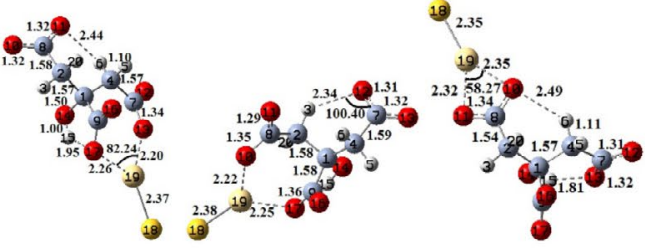

6

7
5
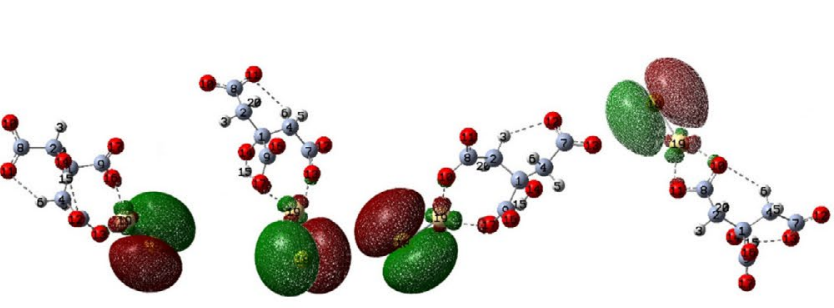

$\mathrm{HOMO}$

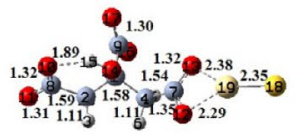

8

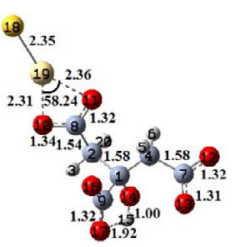

9

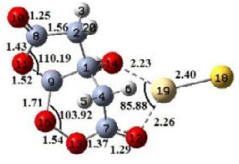

10

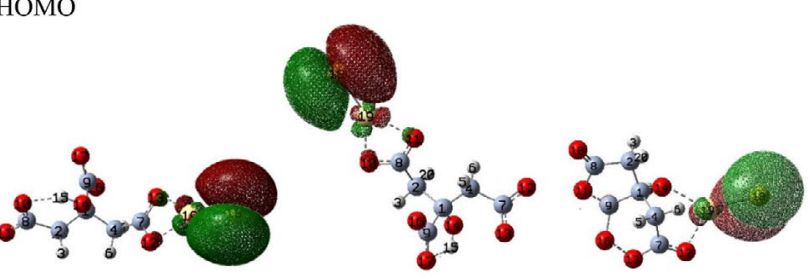

LUMO

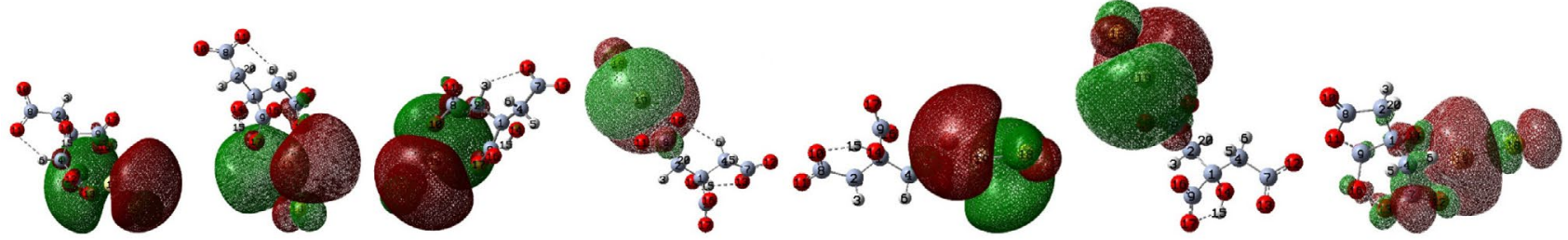

Figure 3. Selected geometrical parameters of the systems citrate ion-CdS whereby bond lengths are in angstroms $(\AA)$ and angles in ${ }^{\circ}$. HOMO and LUMO surfaces are depicted for all the configurations.

the dissociation energy to $-283.34 \mathrm{KJ} / \mathrm{mol}$ and the charge of Cd to -0.02 au. Structures 1-3 all showed similar absolute electronegativity values of $1.60 \times 10^{-20} \mathrm{~J}, 1.53 \times 10^{-20} \mathrm{~J}$ and $1.52 \times 10^{-20} \mathrm{~J}$, respectively. HOMO/LUMO gaps of structures 1 and 3 were very similar, with values of $2.40 \times$ $10^{-19} \mathrm{~J}$ and $2.68 \times 10^{-19} \mathrm{~J}$, respectively, while that of structure 2 was of $1.76 \times 10^{-18} \mathrm{~J}$ indicating its lower ability as a conductor in comparison.

The next set of structures (4-10) are the energy minima geometries of the interaction between citrate ion and CdS. As in structures 1-3, the transfer of electrons happens from the citrate ion to CdS. Observing Fig. 1, the LUMO is denser on Cd, which indicates it is prone to accepting electrons. It can also be seen that the HOMO of the citrate ion lies mostly on the deprotonated carboxyl groups from $(\mathrm{O} 16-\mathrm{C} 9-\mathrm{O} 17)^{-}$, to a lesser extent on (O10-C8-O11)and on $(\mathrm{O} 12-\mathrm{C} 7-\mathrm{O} 13)^{-}$. The most stable structures of this set (4-6) show interactions between $\mathrm{Cd} 19$ and the (O16C9-O17)- group.

Configuration 4 is the most stable structure of this set with a dissociation energy of $-518.36 \mathrm{KJ} / \mathrm{mol}$. The interaction of $\mathrm{Cd} 19$ is with $\mathrm{O} 13$ and O16, with delocalization indices of $\mathrm{DI}(\mathrm{O} 13, \mathrm{Cd} 19)=0.30$ and $\mathrm{DI}(\mathrm{O} 16, \mathrm{Cd} 19)=$ 0.32 . The charges of $\mathrm{Cd}$ and $\mathrm{S}$ were of $1.21 \mathrm{au}$ and $-1.38 \mathrm{au}$, respectively. Structure 5 has a dissociation energy of $-514.16 \mathrm{KJ} / \mathrm{mol}$, very close to that of structure 4 . Its interactions also occur with oxygens of different deprotonated carboxyl groups. Its DI values were of $\mathrm{DI}(\mathrm{O} 13, \mathrm{Cd} 19)=$ 0.31 and $\mathrm{DI}(\mathrm{O} 17, \mathrm{Cd} 19)=0.30$. The charges of $\mathrm{Cd}$ and $\mathrm{S}$
Table 5. NBO charges in a.u. for systems 4-10.

\begin{tabular}{lrrrrrrr}
\hline & \multicolumn{1}{c}{$\mathbf{5}$} & \multicolumn{1}{c}{$\mathbf{6}$} & $\mathbf{7}$ & $\mathbf{8}$ & $\mathbf{9}$ & $\mathbf{1 0}$ \\
\hline $\mathrm{C} 1$ & 0.29 & 0.28 & 0.29 & 0.28 & 0.28 & 0.29 & 0.15 \\
$\mathrm{C} 2$ & -0.52 & -0.52 & -0.53 & -0.52 & -0.53 & -0.51 & -0.27 \\
$\mathrm{H} 3$ & 0.22 & 0.21 & 0.27 & 0.23 & 0.19 & 0.23 & 0.14 \\
$\mathrm{C} 4$ & -0.54 & -0.53 & -0.53 & -0.55 & -0.51 & -0.53 & -0.27 \\
$\mathrm{H} 5$ & 0.21 & 0.21 & 0.22 & 0.22 & 0.25 & 0.23 & 0.15 \\
$\mathrm{H} 6$ & 0.27 & 0.26 & 0.22 & 0.23 & 0.20 & 0.20 & 0.12 \\
$\mathrm{C} 7$ & 1.01 & 1.03 & 1.00 & 1.00 & 1.05 & 1.00 & 0.52 \\
$\mathrm{C} 8$ & 1.00 & 0.99 & 1.00 & 1.05 & 1.00 & 1.04 & 0.48 \\
C9 & 0.98 & 0.99 & 0.98 & 0.96 & 0.96 & 0.97 & 0.50 \\
O10 & -0.94 & -0.94 & -1.00 & -0.94 & -0.93 & -0.95 & -0.32 \\
O11 & -0.93 & -0.93 & -0.84 & -0.94 & -0.93 & -0.92 & -0.34 \\
O12 & -0.89 & -0.86 & -0.93 & -0.92 & -0.96 & -0.96 & -0.42 \\
O13 & -0.97 & -1.02 & -0.95 & -0.94 & -0.90 & -0.92 & -0.20 \\
O14 & -0.87 & -0.88 & -0.87 & -0.90 & -0.90 & -0.91 & -0.49 \\
H15 & 0.51 & 0.51 & 0.50 & 0.54 & 0.54 & 0.53 & 0.29 \\
O16 & -1.02 & -0.84 & -0.81 & -0.96 & -0.96 & -0.90 & -0.16 \\
O17 & -0.82 & -1.01 & -1.02 & -0.89 & -0.88 & -0.94 & -0.43 \\
S18 & -1.38 & -1.38 & -1.38 & -1.33 & -1.34 & -1.33 & 0.27 \\
Cd19 & 1.21 & 1.21 & 1.20 & 1.14 & 1.15 & 1.15 & 0.66 \\
H20 & 0.20 & 0.21 & 0.19 & 0.24 & 0.23 & 0.22 & 0.13 \\
\hline
\end{tabular}

showed the same values as in structure 4 . In structure 6 , $\mathrm{Cd}$ interacts with 2 oxygens of different groups, with DI values of $\mathrm{DI}(\mathrm{O} 10, \mathrm{Cd} 19)=0.33$ and $\mathrm{DI}(\mathrm{O} 17, \mathrm{Cd} 19)=0.31$. Its dissociation energy is very close to that of structures 4 and 5 , with a value of $-506.40 \mathrm{kcal} / \mathrm{mol}$. The charges of $\mathrm{Cd}$ 
and $\mathrm{S}$ were almost the same as in the last two structures, with values of 1.20 and -1.38 au, respectively. Structures 4-6 had similar values of HOMO/LUMO gaps and absolute electronegativities.

Configuration 7, with a dissociation energy of $-499.44 \mathrm{KJ} / \mathrm{mol}$ depicts the interaction between Cd19 and two oxygens of the same functional group with $\mathrm{DI}(\mathrm{O} 10, \mathrm{Cd} 19)=0.28$ and $(\mathrm{DI}(\mathrm{O} 11, \mathrm{Cd} 19)=0.30$. It shows two hydrogen bonds with $\mathrm{DI}(\mathrm{H} 6, \mathrm{O} 10)=0.04$ and $\mathrm{DI}(\mathrm{O} 13, \mathrm{H} 15)=0.09$. The charges of $\mathrm{Cd}$ and $\mathrm{S}$ were of 1.14 au and -1.33 au. Configuration 8 interacts with two oxygens of the functional group $(\mathrm{O} 12-\mathrm{C} 7-\mathrm{O} 13)^{-}$with $\mathrm{DI}(\mathrm{O} 12, \mathrm{Cd} 19)=0.30$ and $\mathrm{DI}(\mathrm{O} 13, \mathrm{Cd} 19)=0.30$ but only has one hydrogen bond with $\mathrm{DI}(\mathrm{O} 10, \mathrm{H} 15)=0.07$. This could account for a smaller dissociation energy of -478.53 $\mathrm{KJ} / \mathrm{mol}$. The charges of $\mathrm{Cd}$ and $\mathrm{S}$ are similar to those of structure 7 , with values of 1.15 au and -1.34 au, respectively. For Structure 9, similarly as in structure 7, the interaction between $\mathrm{Cd}$ and citrate is with the same functional group, with $\mathrm{DI}(\mathrm{O} 10, \mathrm{Cd} 19)=0.30$ and $\mathrm{DI}(\mathrm{O} 11, \mathrm{Cd} 19)=$ 0.27 . It only has one hydrogen bond with $\mathrm{DI}(\mathrm{H} 15, \mathrm{O} 17)=$ 0.07 with a dissociation energy of $-470.91 \mathrm{KJ} / \mathrm{mol}$. Absolute electronegativity for systems 7-9 have similar values of electronegativity $\left(1.48 \times 10^{-18} \mathrm{~J}\right.$ for 7 and $1.49 \times 10^{-18} \mathrm{~J}$ for structures 8 and 9). Their HOMO/LUMO gaps are quite similar, with values of $3.12 \times 10^{-20} \mathrm{~J}, 3.20 \times 10^{-20} \mathrm{~J}$ and $3.19 \times 10^{-20} \mathrm{~J}$.

The last structure, configuration 10 portrays the least stable structure with a dissociation energy of $-241.98 \mathrm{KJ} /$ $\mathrm{mol}$. This great difference in energy could be due to a bond formed between $\mathrm{O} 13$ and $\mathrm{O} 16$ with $\mathrm{DI}(\mathrm{O} 13, \mathrm{O} 16)=1.04$. As for the interactions between $\mathrm{Cd}$ and oxygens, $\mathrm{DI}(\mathrm{O} 12, \mathrm{Cd} 19)=0.30$ and $\mathrm{DI}(\mathrm{O} 14, \mathrm{Cd} 19)=0.30$. The charges of $\mathrm{Cd}$ and $\mathrm{S}$ were of 0.66 and 0.27 , greatly influenced by the O13-O16 bond. This last structure has an absolute electronegativity of $3.28 \times 10^{-20} \mathrm{~J}$ and a larger $\mathrm{HOMO} / \mathrm{LUMO}$ gap of $1.80 \times 10^{-18} \mathrm{~J}$.

\section{Conclusions}

The oxygens in the citrate ion played on important role on the interaction between it and $\mathrm{Cd}^{2+} / \mathrm{CdS}$. This was described by NBO charges, delocalization indices, $\mathrm{HOMO} /$ LUMO surfaces, gap and electronegativity. The transfer of electrons occurs from the citrate ion to $\mathrm{Cd}^{2+}$ or CdS. The most stable structures are formed when the deprotonated carboxyl groups on the citrate ion with greater HOMO density participate. The calculations that support this were dissociation energies, charges, delocalization indices, $\mathrm{HOMO} / \mathrm{LUMO}$ and electronegativity.

The most stable structure for citrate ion- $\mathrm{Cd}^{2+}$ was formed from the interaction $\mathrm{DI}(\mathrm{O} 12, \mathrm{Cd} 18)=0.51$, portraying 3 hydrogen bonds. The most stable structure for citrate ion-CdS displayed $\mathrm{DI}(\mathrm{O} 13, \mathrm{Cd} 19)=0.30$ and $\mathrm{DI}(\mathrm{O} 16, \mathrm{Cd} 19)=0.32$ with also 3 hydrogen bonds. The least stable structures 3 and 10 both show the formation of a O13-O16 bond with DI's of 1.08 and 1.04 au, respectively and no hydrogen bonds.

\section{Acknowledgements}

CONACyT and ACARUS of the University of Sonora are thanked for their support.

\section{References}

1. G. Hodes, Chemical Solution Deposition of Semiconductor Films, Marcel Dekker Inc., New York, Basel, 2003.

\section{DOI:10.1201/9780203909096}

2. Rabeel, Z.; Abbas, M.; Basit, M.; Shah, N. A.; Ahmad I.; Ul Hassan, M. S. U. J. Adv. Nanomater. 2017, 2, 112-120.

3. J. Barman, J. P. Borah, K. C. Sarma, Chalcogenide Letters 2008, 5, 265-271.

4. H. Khallaf, I. O. Oladeji, G. Chai, L. Chow, Thin Solid Films 2008, 516, 7306-7312. DOI:10.1016/j.tsf.2008.01.004

5. J. L. Chen, S. F. Yang, C. C. Wu, S. Ton, Separation and Purif. Tech. 2011, 79, 157-163.

DOI:10.1016/j.seppur.2011.02.029

6. S. Soundeswaran, O. Senthil Kumar, R. F. Dhanasekaran, Mater. Lett. 2004, 58, 2381-2385.

DOI:10.1016/j.matlet.2004.02.012

7. A. de Leon, M. C. Acosta-Enríquez, A. F. Jalbout, A. Apolinar-Iribe, S.J. Castillo, J. Mol. Struct: THEOCHEM 2010, 957, 90-93. DOI:10.1016/j.theochem.2010.07.013

8. A. de Leon, F. Rocha-Alonso, E. F. Velázquez, S. J. Castillo, A. Apolinar-Iribe, Chalcogenide Letters, 2013, 10, 555-564.

9. A. de Leon, M. C. Acosta-Enríquez, S. J. Castillo, D. Berman-Mendoza, A. F. Jalbout, J. Mol. Struct: THEOCHEM 2010, 951, 34-36. DOI:10.1016/j.theochem.2010.04.003

10. A. de Leon, M. Ruiz-Preciado, M. A. Quevedo-Lopez, A. G. Rojas-Hernandez, A. de Leon, A. Apolinar-Iribe, R. Ochoa-Landin, G. Valencia-Palomo, S. J. Castillo, Digest J. Nanomater. Biostruct. 2017, 4, 1057-1067.

11. Gaussian 09, Revision A.02, M. J. Frisch, G. W. Trucks, H. B. Schlegel, G. E. Scuseria, M. A. Robb, J. R. Cheeseman, G. Scalmani, V. Barone, G. A. Petersson, H. Nakatsuji, X. Li, M. Caricato, A. Marenich, J. Bloino, B. G. Janesko, R. Gomperts, B. Mennucci, H. P. Hratchian, J. V. Ortiz, A. F. Izmaylov, J. L. Sonnenberg, D. Williams-Young, F. Ding, F. Lipparini, F. Egidi, J. Goings, B. Peng, A. Petrone, T. Henderson, D. Ranasinghe, V. G. Zakrzewski, J. Gao, N. Rega, G. Zheng, W. Liang, M. Hada, M. Ehara, K. Toyota, R. Fukuda, J. Hasegawa, M. Ishida, T. Nakajima, Y. Honda, O. Kitao, H. Nakai, T. Vreven, K. Throssell, J. A. Montgomery, Jr., J. E. Peralta, F. Ogliaro, M. Bearpark, J. J. Heyd, E. Brothers, K. N. Kudin, V. N. Staroverov, T. Keith, R. Kobayashi, J. Normand, K. Raghavachari, A. Rendell, J. C. Burant, S. S. Iyengar, J. Tomasi, M. Cossi, J. M. Millam, M. Klene, C. Adamo, R. Cammi, J. W. Ochterski, R. L. Martin, K. Morokuma, O. Farkas, J. B. Foresman, and D. J. Fox, Gaussian, Inc., Wallingford CT, 2016. 
12. M. Head-Gordon, J. A. Pople, M.J. Frisch, J. Chem. Phys. Lett. 1988, 153, 503-506.

DOI:10.1016/0009-2614(88)85250-3

13. T. H. Dunning, Jr., P. J. Hay, In Modern Theoretical Chemistry; Schaefer III, H. F., Ed. Vol. 3, Plenum Press: New York, 1976; pp. 1-28.

14. S. Simon, M. Duran, J. J. Dannenberg. J. Chem. Phys. 1996, 105, 11024-11031. DOI:10.1063/1.472902
15. R. G. Pearson Inorg. Chem. 1988, 27, 734-740. DOI:10.1021/ic00277a030

16. F. Weinhold, "Natural Bond Orbital Methods," in Encyclopedia of Computational Chemistry, Schleyer, P.v.R; Allinger, N. L.; Clark, T.; Gasteiger, J.; Kollman, P. A.; Schaefer III, H. F; Schreiner P. R. (Eds.), (John Wiley \& Sons, Chichester, UK, 1998), Vol. 3, pp. 1792-1811.

17. T.A. Keith, AIMALL (Version 19.02.13), TK Gristmill Software, Overland Park KS, USA, 2019 (aim.tkgristmill.com)

\section{Povzetek}

Teoretične študije o konformacijski analizi, geometrijski optimizaciji in frekvencah na ravni MP2/LANL2DZ predstavljajo citrat kot obetavnega kandidata za kompleksirajoče sredstvo za kadmijev (II) ion $\left(\mathrm{Cd}^{2+}\right)$ in kadmijev sulfid (CdS). Za analizo medsebojnih vplivov med pridobljenimi konfiguracijami so bili uporabljeni naravni naboji orbital (Natural Bond Orbital or NBO), indeksi delokalizacije, HOMO/LUMO vrzeli in površine ter absolutne vrednosti elektronegativnosti. Najbolj stabilne strukture so vključevale interakcijo med LUMO Cd ${ }^{2+} / \mathrm{CdS}$ in najbolj gostim območjem HOMO citratnega iona. 